\title{
The Internal Audit Process in the Cooperative Credit Banks: Consequences and Perspectives after the Reform
}

\author{
Adalberto Rangone \\ Adjunct Professor Information and Strategic Management \\ Department of Economics and Management \\ University of Pavia \\ Via San Felice, 5 - 27100 Pavia
}

\begin{abstract}
The need of the banking sector to be aligned with the Internal Audit best practices involves inevitably questions concerning the best practices. The issue of the internal review within a company has been already widely studied and a considerable literature has been written, however, nowadays literature about this important function within the Cooperative Credit Banks is still limited. The new scenario which are outlining day by day in accordance with the Law nr. 49/2016 let to imagine a significant metamorphosis due to the subtle existing link between the governance structure characterizing the new Cooperative Banking Groups and the decisional autonomy of the individual CCBs on the evaluation methods of the assets and, particularly, of the financial instruments. Today, we can just suppose about the influences that might result from ongoing processes; nevertheless, before they occur, it is important trying to understand which is the current procedure of Internal Audit and how it is essential for an efficient execution of the banking functions in order to facilitate a comparative analysis with possible future developments. Therefore, this paper aims to investigate the current process of Internal Audit within the Cooperative Credit Banks. A process that generally seems to be realized evenly just for its own purposes but, according to the provisions of the Law nr. 49/2016, actually shows numerous facets and even more doubts.
\end{abstract}

Keywords: Internal Audit, Banking System, Risk Management, Strategic Management, Corporate Governance

\section{The application context of the recent Reform: a brief recap of CCBs' history}

The tradition of the Italian Rural Banks and the Cooperative Credit Banks began from the end of the $19^{\text {th }}$ century. The first Rural Bank was born in 1883 in Loreggia in the province of Padua (CREDI Umbria, 2018). From that time, and even more after the encyclical Rerum Novarum by Pope Leone XIII dated 1891, the Rural Banks spread throughout the Italian territory in order to support and encourage the born of the entrepreneurial and, above all, rural initiatives in the territory of reference (BCC Marche, 2018). After just four years from the foundation of the first Rural Bank, the Federation of the Rural Banks was constituted and was organized as a unitary reality. In 1937, the consolidated text about the Rural and Artisanal Banks reinforces their organization as cooperatives having as their principal aim the credit practice towards farmer and artisans (T.U.C.R.A, 1937).The Italian Federation (Federcasse) was constituted in 1950 and today it still remains the sole National body after the liquidation of the National Body of the Agricultural Rural Banks and Auxiliary Body (1979) which carried out important tasks of coordination, assistance and control.

ICCREA was founded in 1963 in order to carry out credit function, technical intermediation and financial assistance, while the Fondo di Garanziadei Depositanti was constituted in 1978 (it was the first example of a banking self-defense bodyin Italy) and then was turned into the "Fondo di Garanziadei Depositanti e del Credito Cooperativo"(1997). The "Carta deiValori del Credito Cooperativo" (below defined "Charter of Values") was written in 1993. It contains the fundamental principles which the CCB's core is based on and it makes them different from the rest of the credit institutes.

The new Consolidated Text about the laws on banking and credit topics in force from $1^{\text {st }}$ January 1994, finally defines the most modern scope of operations of the CCBs which are still conditioned by the previous TUCRA dated 1937. This allowed the CCBs to offer services and products in the same way as the most general banking system, and also to have the possibility to join new partners coming from their areas of responsibility. 
The ICCREA Holding was born in 1995 and "it started to operate through interests in ICCREA Banca, Banca Agrileasing and Aureo Gestioni” (ICCREA, 2018).

The Law nr. 49/2016 was published in the Official Journal nr. 87 in April 2016. It plans and establishes that all the BCCs are included into a Cooperative Banking Group even if considering some exceptions. The reverse merger between ICCREA Holding and ICCREA Banca was in September 16, 2016 and the latter was put at the top of ICCREA Banking Group.

\subsection{The provisions of the Law nr. 49, April $8^{\text {th }}, 2016$}

Before making any considerations on the specific provisions established by the Law Nr. 49, it should be specified that although its reformative function, this law did not actually change neither the fundamental principle nor the internal organization of the CCBs. The topic of this law is the "system" through which the CCBs cooperate in order to carry out their task at their best. The articles 3 and 5 defined by the "Charter of Values" and titled "Autonomy" and "Cooperation", allow understanding appropriately these terms: Autonomy is one of the fundamental principles of the Cooperative Credit. This principle is vital and fruitful only if it is coordinate, linked and included into the "system" of the Cooperative Credit. [3]

And: The cooperative style is the way for success. Joining forces, working group, the fair sharing of the aims are the future of the cooperative credit. The cooperation among cooperative banks by means of local, regional, national and international structures is the condition to preserve their autonomy and to improve the service towards partners and customers. [5]

The Charter of Values shows how the individual operations of each single Cooperative Credit Bank have been identified in a higher scope called the "Cooperative Credit System" and it must be related to it. Therefore, it is a system composed of different levels: local, national and even international. The various local Federations through the drafting of protocols of agreements are able to regulate and defend the interests of the associated banks (i.e. see the strategic plan for the opening of branches).

Through the local Federations the individual BCCs form a national federation - Federcasse - which ensures the representation and protection of the category, manages the national collective labor agreement, ensures legal advice, tax, organizational, communication, training in favor of local Federations, of other member bodies and Cooperative Credit Banks, carries out study and research activities on the credit system and in particular on Cooperative Credit. While the Federcasse is a form of "institutional" association with national and international efficacy, by joining the European Association of Co-operative Banks, the establishment of ICCREA Holding (1995) has consolidated in the Group all the bank business activities now managed and satisfied by ICCREA Banca Spa. Coming now to the specifications of the reform, we can explain tout court what has been confirmed about the typical practice of the BCCs:

- At least $95 \%$ of disbursements must be made in the bank own operating area;

- The vote remains per capita then the voting rightis not attributed in relation to the percent of shares held;

- $70 \%$ of profits are allocated to an indivisible reserve.

Instead, it is envisaged:

- An increase in the minimum number of members of each CCB, from 200 to 500 and the related increase in the capital that can be held, from 50 thousand to 100 thousand euros per capita;

- the obligation for all CCBs to join a Cooperative Banking Group by signing the cohesion pact. Control is held by a parent company;

- a non-adhering clause to the Cooperative Banking Group on condition that net worth exceeds $€ 200$ million.

- The Raiffeisen Casse system of Alto Adige may constitute a provincial Group by virtue of its cultural peculiarities.

These provisions, which in principle do not seem to change the function of the CCBs, actually imply substantial developments in terms of governance with real repercussions on the strategic choices of individual banks and, obviously, on the composition of products and offered services. In fact, highlighting the non-adhering clause we can note CCB' world has clearly arranged itself on three fronts: one as expression of the Cooperative Banking Group led by ICCREA Spa holding, a second part leaded by Cassa Centrale Banca -Credito Cooperativodel Nord Est SpA and finally a third part leaded by the provincial group of the Raiffeisen Casse of Alto Adige. 
This solution therefore seems to remove the CCBs from the principle of unity and comparison so much declaimed by the Charter of Values, since cohesion (at first vivid due to the absence of regulatory constraints) is today transformed into a de facto juxtaposition of the interests of three clearly distinct company groups. But this legislative provision went much further. Articlenr. 2, paragraph 3-quater provides that:

After the contribution the transferring Cooperative Credit Bank, which maintains the indivisible reserves less the payment as per paragraph 3-ter, modifies its corporate purpose to exclude the exercise of banking activity and undertakes to maintain the mutualist clauses as per article 2514 of the Italian Civil Code, as well as to provide functional services to members in order to maintain the relationship with the receivingjoint stock company, training and information services on the savings issues and the promotion of assistance programs. The right of withdrawal provided for by article 2437, first paragraph, letter a) does not belong to the shareholders.

Therefore, while maintaining the mutualist purposes typical of the cooperatives, at the time of the contribution the CCBs should place the banking activity under the control of the parent company and the companies controlled by it. Some authors (Malvezzi V., 2017) have raised countless doubts about the actual role that the CCBs will play when the services and products could be sensibly standardized (although they are offered mainly in the reference area) compromising in this way the original function that distinguished them from the rest of the banking system (Bonfanti A., 2009). However, it is important to underline that the BCCs themselves have a number of concerns:

At the 2016 meeting in Lecco, we remarked that "the birth of a plurality of Cooperative Groups would have made easier our progressive marginalization in the market, perhaps making us disappear a piece at a time." [...] With the division, investments are duplicate, the consultants will multiply and the disorientation will spread, also because the membership of a group or another will not follow geographic or territorial delimitations; with perspectives of overlap and the push to the competition "between similar". [...] We all know how much energy has been used to find a convergence of interests, what options have been proposed and how many opportunities have been burned in recent months to compose the situation and avoid a division that certainly does not make us stronger in front of the market and the Supervisory Authorities, both national and European (FederazioneLombardadelle BCC, 2016).

In addition, the concerns involve also governance as well as internal control issues, creating a delicate intertwining in which the CCBs will be evaluated on the basis of asset quality review and assessed in light of the risk classification. The legislation then implies a further scenario considered to be of extreme importance: the substantial opening up to additional Italian and foreign investors. The law nr. 49/2016 in fact regulates the control range of the Parent Company in such a way that $51 \%$ is distributed among the countless CCBs while $49 \%$ is placed on the market and therefore becomesinevitably attractive to international giants (Malvezzi V., 2017). In order to clarify the concept, the practice was further underlined in the update of the Circular nr. 285 of the Bank of Italy:

Furthermore, the statutory regulations must be such that they do not hinder the opening of capital to investors other than cooperative credit banks and the prompt recapitalization of the group through recourse to the risk capital market, where this becomes necessary.

Therefore, in the light of what Charter of Values expresses, if CCBs' autonomy can be preserved through constant interaction with the "system" where the single entities should have the opportunity to compare "on a par", it seems appropriate trying to understand which consequences can be behind a real "secession" that has revolutionized the original CCBs' system arranged on three adverse fronts and now opened to foreign investors.

Our Latin fathers used to pronounce themselves with the masterly motto "cui prodest?". Far from wanting to deal here with issues of international governance, we will continue beyond leaving the attentive reader the burden of a wise interpretation.

\section{The Internal Audit system in the Cooperative Credit Banks}

\subsection{CCBs: parent companies or companies under control?}

The reform law has clearly set out hard times for the CCBs in particular as regards the sophisticated system of controls that must be established between the holding company and the affiliated CCBs. In fact, the legislation tends to underline that the CCBs' health must in any case remain a priority of the holding company because otherwise the Group's raison d'être would be less (Bindelli M., 2018). 
In this sense, it is useful to consider the singular perspective for which the CCBs affiliated to the Group are transformed "from parent companies to companies under control" by virtue of the fact that according to the Bank of Italy provisions [Part Three, Chapter 5, Section III of Circular nr. 285] the cohesion contract must clearly indicate: the control and intervention activities of the parent company on affiliated banks; in addition, the holding company should perform the following tasks:[...] specific criteria for the selection of exponents based on merit, having regard in particular to the skills demonstrated and the results achieved in the administration, management and control of the affiliated banks as well as the risk classification of the same according to the system adopted by the group for control and intervention purposes (see Section 1.4);

- defines uniform methods, tools and criteria of the self-assessment process of the corporate bodies of the affiliated banks, with the aim of achieving high quality standards of the corporate bodies, without prejudice to the responsibility of the bodies of each company for the correctness and completeness of the self-assessment conducted;

- adopts procedures aimed at verifying, in an efficient and timely manner, compliance by the affiliated banks with the provisions regarding the requirements and criteria of the corporate officers of the banks established pursuant to art. 26 of the Banking Act (Italian T.U.B.);

- if necessary solicits the forfeiture, replacement or adoption of appropriate measures to fill gaps in the components that do not comply with the requirements and criteria required by statutory or regulatory provisions or by the provisions of the supervisory authority; in the event of inaction by the competent corporate bodies, exercises the powers conferred by the cohesion contract to the parent company on the appointment and revocation of the bodies of the affiliated banks;

Having said that, now we examine the current context in which the new broad control process of the holding company should take place in relation to the affiliated CCBs.

\subsection{The regulatory provisions concerning Internal Auditing}

The principle of implementation is referred to the interpretation of the Bank of Italy provisions.It is more specifically referred to the Circular no. 285 of December 17, 2013 and subsequent updates regarding control and internal audit. In this context, consistently with the drafting of an audit plan, the internal audit function is aimed at assessing the completeness, adequacy, functionality and reliability of the other bodies that make up the control system, and therefore of the risk management process, compliance with regulations and various corporate processes. The internal audit function should aim to assess consistency and corporate compliance with the risk objective system (RAF). Furthermore, through inspections of an inspective nature, it verifies:

- the regularity of the various company activities, including those outsourced, and the evolution of risks both in the general management of the bank and in the branches. The frequency of inspections is consistent with the activity performed and the propensity to risk; however, random and unannounced inspections are also conducted;

- the monitoring of compliance with the rules of the activity of all company levels;

- the respect, in the various operating sectors, of the limits set by the delegation mechanisms, and the full and correct use of the information available in the various activities;

- the effectiveness of the powers of the risk control function to provide prior opinions on the coherence with the RAF of the most significant transactions;

- the adequacy and correct functioning of the processes and methods for assessing company activities and, in particular, financial instruments;

- the adequacy, overall reliability and security of the information system (ICT audit);

- the removal of anomalies found in the operation and functioning of controls ("follow-up" activities).

The Bank of Italy also underlines that periodic tests must be carried out on the functioning of the operating and internal control procedures together with the checks of the verification programs in order to highlight the shortcomings found. The internal audit function also monitors the business continuity plans of service providers and critical suppliers. Therefore, if the auditing body becomes aware of critical issues that have occurred during the activity of auditing the accounts, it must intervene so that the competent functions become proactive in overcoming them. As previously stated, given the importance of the assessments of the internal audit body on the other corporate control bodies, with reference to risk managementthe Internal Audit process also assesses:

- the organization, powers and responsibilities of the risk control function, also with reference to the quality and adequacy of the resources assigned to it; 
- the appropriateness of the hypotheses used in sensitivity and scenario analyses and stress tests;

- alignment with the best practices spread in the sector.

Therefore, considering more specifically this last point that underlines the need to align with the best practices spread in the sector, the question arises naturally in what sense this concept is defined in the field of Internal Audit and how it is applied within the CCBs" "system" previously described.

\subsection{The importance of Local Federations}

In order to carry out the investigation about the current internal audit best practice in the context of the various solutions adopted, we've considered appropriate focusing on the important role of the local Federations. In fact, it is a shared practice among the CCB's to outsource the Internal Audit functions in local Federations (managed as joint stock companies).

The outsourcing of Internal Audit functions is clearly contemplated by the Bank of Italy (see Section IV of Circular nr. 285) provided that precise criteria are met, such as: the preliminary forecast of objectives, methodology and frequency of controls, the method to develop reporting system is developed towards the referent for internal audit activities is established, the links with the control activities carried out are established, as well as the confidentiality and ownership of the results obtained.Alternatively, the Cooperative Credit Bank can carry out the innumerable third-level control functions internally.

In this case, however, it will have the task of transmitting its own reports on the review activity performed to the local Federation. This practice - contemplated by the CCBs' Statute - makes us to understand the importance of the local Federation as an associativeinstitution but also as a coordinating and controlling body. It should also be emphasized that the local Federations carry out amirroring function of the associated CCBs and a dual nexus: the financial-economicone - since the management expenses to support the activities of the company are borne by the associated banks - and the operational one- in addition to the advice provided to the CCBs, local Federations perform important functions for them (FederazioneBCC Emilia Romagna, 2017).

Table 1. Example of production value reported in the income statement of a Local Federation

\begin{tabular}{|l|r|r|r|r|}
\hline Services Rendered & \multicolumn{1}{|c|}{$\begin{array}{c}\text { toMembers } \\
\mathbf{2 0 1 6}\end{array}$} & \multicolumn{1}{c|}{$\begin{array}{c}\text { To non- } \\
\text { Members } \\
\mathbf{2 0 1 6}\end{array}$} & \multicolumn{1}{c|}{$\begin{array}{c}\text { To } \\
\text { Members } \\
\mathbf{2 0 1 5}\end{array}$} & $\begin{array}{c}\text { To non- } \\
\text { Members } \\
\mathbf{2 0 1 5}\end{array}$ \\
\hline Membership fee for Institutional Services & 8.423 .833 & - & 8.215 .124 & - \\
\hline $\begin{array}{l}\text { Istitutional Services } \\
\text { CommunicationCampaign }\end{array}$ & - & - & 80.466 & - \\
\hline Internal Audit Service and ISA & 1.321 .610 & 117.750 & 1.284 .714 & 141.045 \\
\hline Training Service & 389.849 & 10.755 & 467.923 & 5.160 \\
\hline Wages Service & 927.780 & 134.220 & 1.013 .364 & 143.901 \\
\hline $\begin{array}{l}\text { Human Resources Service and } \\
\text { Applications }\end{array}$ & 74.919 & 64.046 & 66.149 & 18.548 \\
\hline ComplianceService & 175.600 & - & 120.417 & - \\
\hline Professional Consultancy & 188.370 & 115.500 & 199.894 & 197.073 \\
\hline $\begin{array}{l}\text { Services (Development Fund } \\
\text { commissions) }\end{array}$ & - & 64.500 & & 49.830 \\
\hline Reimbursement of expenses & 2.495 & - & 8.240 & - \\
\hline Sale of consumables & 2.510 & - & 4.496 & - \\
\hline & $\mathbf{1 1 . 5 0 6 . 9 6 6}$ & $\mathbf{5 0 6 . 7 7 1}$ & $\mathbf{1 1 . 4 6 0 . 7 8 6}$ & $\mathbf{5 5 5 . 5 5 7}$ \\
\hline
\end{tabular}

Source: our elaboration with public data from Federazione Lombarda, Reports and Balance sheet 2016.

Internal Audit is an example of that functions and expresses an important share of the company income.Thus, by virtue of a precise audit plan, local Federations' body responsible for the internal audit assists the associated CCBs by sending them periodical reports and by "men-days" spent in front office as well as in back office (Federazione Veneta, 2016). 
Figure 1. Interventions carried out by Local Federations for the associated CCBs in the scope of their Internal Audit plans

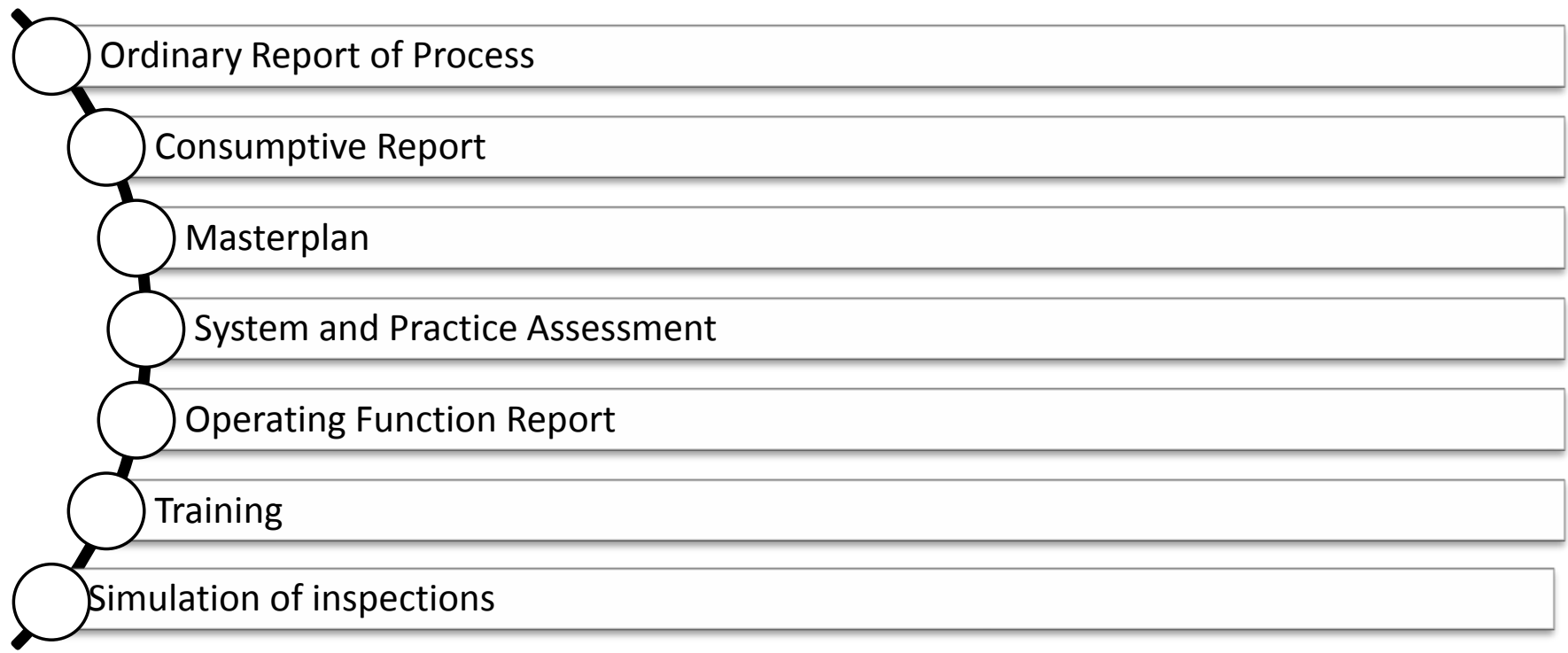

Source: our elaboration

The audit activity has for its purpose the careful and scrupulous investigation of the processes and business areas considered most sensitive. Specifically, a comparison carried out on the internal audit activities promoted by the local Federations revealed that checks should be carried out on the following themes / key processes for a correct internal audit function:

- Credit

- ICAAP

- Finance

- Information systems (IT)

- Branches

- Anti-Money Laundering

- Remuneration and incentive systems

- Collections and Payments

- Governance and Management of Liquidity Risk

- Outsourcing of important operating functions and control

- Risk Appetite Framework and Risk Management Function

- Follow up on the verification activities carried out previously

- Conflict of interest

- Statement

Finally, the Internal Audit activity carried out by local Federations is completed with the attendance of its own responsible officers to the board of directors or the meetings of the board of statutory auditors promoted by associated CCBs in order to be constantly updated on the developments of the individual banking situations and then to perfect the informativesystem. 
Figure 2. Scheme of IA Scheme of IA processes carried out by local Federations

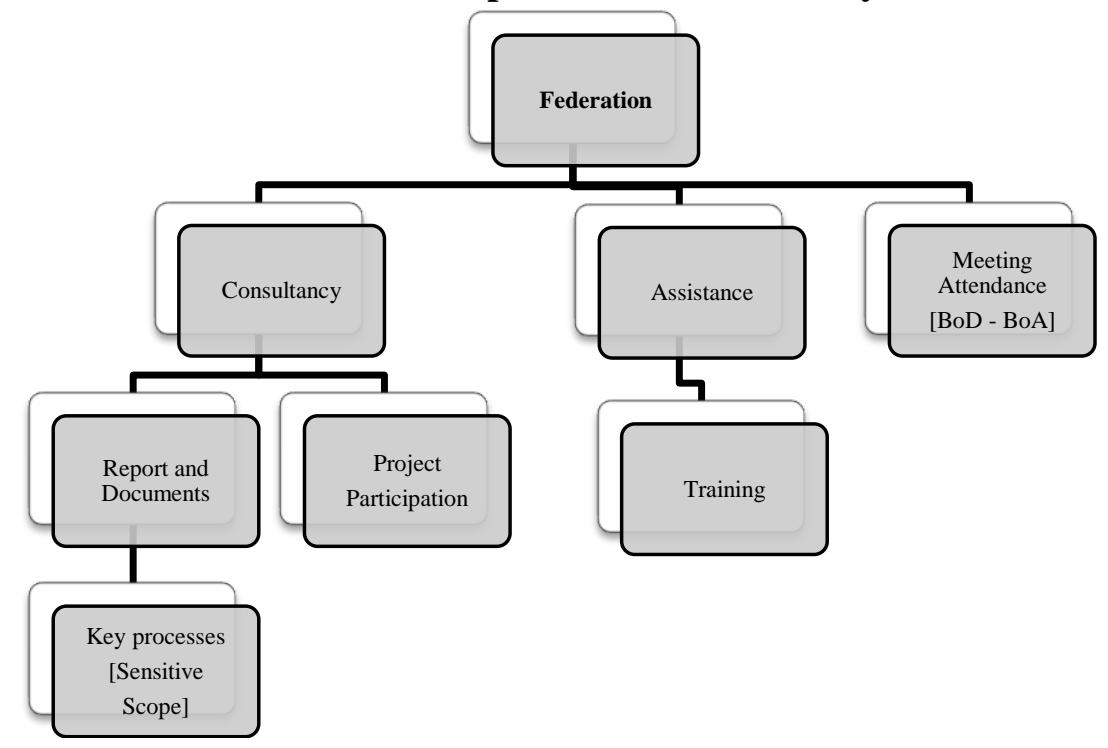

Source: our elaboration

Therefore, if we want to refer to what Bank of Italy envisaged, we can conclude that the term best practice on IA should be understood as a control process that homogeneously involvesspecific key processes in sensitive areas mainly made in outsourcing in order to support the operation and the efficiency of CCBs, through consultancy and assistance activities, through the assiduous presence of managers in the meetings of the board of directors and the board of statutory auditors as well as through interaction with the other control bodies.

\subsection{Emerging models and perspectives}

Although it may be considered today the most widespread, the practice previously examined - which enhances the fundamental role of the Local Federations - is not the only one. In fact, alternatives are found in cases where the audit process is entrusted directly to the Group'sholding company or to an external company that is not the Federation. A first concrete example can be found in the reality of the CCBs Raiffeisen who, in light of Law nr. 49/2016, started the transfer of the Internal Audit and Credit departments from the Cooperative Federation Raiffeisen to the Cassa Centrale Raiffeisen, the Group's holding company (Federazione CooperativeRaiffaisen, 2016).

A different case is found in important Cooperative Credit Banksof Piedmont which have delegated the internal audit function to a consortium JSC. The "ServiziBancariAssociatiSpACorsortile" is the result of the sale of a branch of the CCBs Federation of Piedmont, Valle d'Aosta and Liguria in December 2000 and offers outsourced services for the system of the Cooperative Credit Banks (SBA Spa Consortile, 2018). In this way the entrepreneurial and back office functions have been distinguished from the political-institutional function commonly held by the local Federation. Through this solution, therefore, payment systems, IT services, personnel management, tax, financial and credit aspects can be entirely outsourced to a consortium JSC as an alternative to the local federation that would maintain its institutional function only.

Figure 3. Different solutions of outsourcedIA process

\begin{tabular}{|c|}
\hline Model \\
RAIFFEISEN \\
IA outsourced by \\
Group's Holding \\
\hline
\end{tabular}

Source: our elaboration

\begin{tabular}{|c|}
\hline Model \\
TRADITIONAL \\
IA outsourced by \\
Local Federation \\
\hline
\end{tabular}


The models are therefore multiple; however, a careful analysis of the Reform Act previously considered leads us to consider the possible repercussions coming from the opelegis adhesion to a Group. Being in fact in the position of "controlling under control" in the very near future the CCBs could decide to change the current traditional model into a Raiffeisen model in which the III level controls are entirely carried out by the internal control body of the holding company. This scenario is implicitly envisaged and at times incentivized by the legislation itself since, as we have previously examined, one of the important tasks of the holding company will be control over the affiliated Banks.

\section{Conclusions}

The evolutionary path of CCBs leads us to take note that after the great Reform the institutional and banking roles of CCBs could become two elements clearly distinct. If this were to happen, we could therefore contemplate the hypothesis in which the Federations lose their audit function towards the CCBs to maintain exclusively the institutional one. In such a scenario, the CCBs could be forced to opt between the Consortium JSC or the Raiffeisen models. The reader is therefore reminded of the question whether and to what extent the initiatives of the legislator could lead to serious contraindications (given the positive results of the CCBs compared to the rest of the banking system). But this question also concerns an economic sphere that moves away from the field of investigation characterizing this work.

Given the possible repercussions that could derive from the attribution of the internal audit function to the parent company (substantial critical issues in terms of conflict of interest) we believe important the comparison between the "traditional" model and the one defined "Consortium JSC" for the outsourcing of the Internal Audit function. Thus, this work can be clearly considered as a first approach for further studies and researches concerning the I.A. process in CCBs pending the completion of the implementing measures.

\section{References}

Bank of Italy, 2018,Aggiornamento n. 25 del 23 ottobre 2018 alla Circolare nr. 285 del 17 Dicembre 2013, at: https://www.bancaditalia.it/compiti/vigilanza/normativa/archivio-norme/circolari/c285/index.html .

Bank of Italy, 2013, Circolare nr. 285 del 17 Dicembre 2013, at: https://www.bancaditalia.it/compiti/vigilanza/normativa/archivio-norme/circolari/c285/index.html .

BCC Credito Cooperativo, 2018, La cooperazione di credito in Italia, at: http://www.creditocooperativo.it/template/default.asp?i_menuID=35350 .

BCC Credito Cooperativo, 1999, La Carta dei Valori del Credito Cooperativo, at:

http://www.creditocooperativo.it/template/default.asp?i_menuID=7101 .

BCC Credito Cooperativo, 2005, La Carta della Coesione del Credito Cooperativo, at: http://www.creditocooperativo.it/template/default.asp?i_menuID=10611 .

BCC Credito Cooperativo, 2005, La Carta della Finanza libera, forte, democratica, at: http://www.creditocooperativo.it/template/default.asp?i_menuID=35394 .

BCC Umbria, Procedure deliberative in tema di attività di rischio e conflitti di interesse nei confronti di soggetti collegati,2018,at:http://www.bccumbria.it .

Bindelli M., 2018, La governance dei gruppi bancari cooperativi, in Diritto Bancario, Approfondimenti, at: http://www.dirittobancario.it/sites/default/files/allegati/bindelli_m._la_governance_dei_gruppi_bancari_c ooperativi_2018.pdf .

Bodega D.,2011, BCC: ambiente, organizzazione, cultura, in Carretta A. (a cura di), Il credito cooperativo. Storia, diritto, economia, organizzazione, Il Mulino, Bologna.

Bonfanti A., 2009, Le Banche di Credito Cooperativo. Un futuro che viene da lontano, Giuffrè Editore, Milano.

Boscia V., Lopez J.S., 2011,Il posizionamento del sistema cooperativo del credito nel sistema bancario italiano",in Carretta A. (a cura di), Il credito cooperativo. Storia, diritto, economia, organizzazione, Il Mulino, Bologna.

Cassa Centrale Banca - Credito cooperativo del Nord Est, 2018, Balance sheet 2017, at: https://www.cassacentrale.it/ccbcontent0.jsp?XD=3868\&LANGUAGE=IT .

Cassa Centrale Banca - Credito cooperativo del Nord Est, 2017, Balance sheet 2016, at:

https://www.cassacentrale.it/ccbcontent0.jsp?XD=3868\&LANGUAGE=IT .

Cassa Centrale Banca - Group, 2018, Balance sheet 2017, at: 
https://www.cassacentrale.it/ccbcontent0.jsp?XD=3868\&LANGUAGE=IT.

Cassa Centrale Banca - Group, 2017, Balance sheet 2016, at:

https://www.cassacentrale.it/ccbcontent0.jsp?XD=3868\&LANGUAGE=IT .

Federazione Calabrese delle BCC, 2018, Balance sheet 2017, at:

http://www.federcalabria.bcc.it/template/default.asp?i_menuID $=42560$.

Federazione Campana delle BCC, 2018, Balance sheet 2017, at:

$\mathrm{http} / / / \mathrm{www}$. federcampana.bcc.it/template/default.asp?i_menuID $=40069$.

Federazione Emilia Romagna delle BCC, 2018, Balance sheet 2017, at: www.fedemilia.bcc.it/ .

Federazione Friuli Venezia Giulia delle BCC, 2018, I valori, la storia, la differenza del Credito Cooperativo, at: www.bccfvg.it.

Federazione Lazio Umbria Sardegna delle BCC, 2018, Balance sheet 2017, at: https://federlus.it/bilancio/ .

Federazione Lombarda delle BCC, 2017, Reports andBalance sheet2016, at:

http://www.fedlo.it/doc2/default.asp?i_menuID=25083\&i_archivioID=25097 .

Federazione Lombarda delle BCC, 2016, Report on Management, athttp://www.fedlo.it .

Federazione Marchigiana delle BCC, 2014, Balance sheet2013, at:

http://www.fmbcc.bcc.it/content/cart6/3388279194

Federazione Piemonte Valle d'Aosta Liguria delle BCC, 2017, Reports andBalance sheet2016, at: https://www.fabibcc.it/category/contrattualistica-regionale/piemonte-liguria-valle-daosta/ .

Federazione Puglia e Basilicata delle BCC, 2018, Balance sheet 2017, at: http://www.federpb.bcc.it/bilanci/bilancio .

Federazione Siciliana delle BCC, 2018, Balance sheet 2017, at: http://www.creditocooperativosicilia.it/pg.bilanci.lista.php .

Federazione Trentina della Cooperazione, 2018, Balance sheet 2017, at:https://www.cooperazionetrentina.it/Chisiamo/La-Federazione2/Bilanci

Federazione Veneta delle BCC, 2017, Reports andBalance sheet 2016, at: www2 fvbcc.it .

Gazzetta Ufficiale, 2016, Decreto-Legge convertito con modificazioni dalla L. 8 aprile 2016, n. 49, at: http://www.gazzettaufficiale.it/eli/id/2016/02/15/16G00025/sg\%20 .

Gruppo Bancario ICCREA, 2018, Company data, at: https://www.iccreabanca.it/Style\%20Library/Iccrea/attachments/Progetto\%20Governo\%20Societario_Icc rea\%20Banca.pdf .

Gruppo Bancario ICCREA, 2018, The System of Internal Controls 2013, at: http://www.gruppobancarioiccrea.it/Pagine/InvestorRelations/Bilanci-e-rating.aspx .

ICCREA Banca, 2018,Corporate GovernancePolitics, at: https://www.iccreabanca.it/it-IT/Pagine/dati-societari.aspx .

ICCREA Banca, 2018,IntermediateBalance sheets2018, at:https://www.iccreabanca.it/it-IT/Pagine/bilanci.aspx.

ICCREA Banca, 2018, Balance sheets 2017, at:https://www.iccreabanca.it/it-IT/Pagine/bilanci.aspx.

ICCREA Banca, 2017, Balance sheet 2016, at:https://www.iccreabanca.it/it-IT/Pagine/bilanci.aspx.

ICCREA Banca, 2016, Balance sheet2015, at:https://www.iccreabanca.it/it-IT/Pagine/bilanci.aspx.

Malvezzi V., 2018, Sono sempre le banche locali a sostenere le piccole imprese, Economy, in Rassegna Stampa del Credito Cooperativo, n.154, 2018.

Migliorelli M., 2018, New Cooperative Banking in Europe, PalgraveMcmillan, Cham, Switzerland.

Minnetti F., 2013, Banche locali e PMI nel mercato del credito: dalla crisi un forte impulso per rivedere la relazione in chiave evoluzionistica, CASMEF,WorkingPapers, n. 8, Dicembre, 2013.

Raiffeisen LandesbankSüdtirol, 2018, Balance sheet and Income Statement 2000-2017, at: https://www.raiffeisen.it/en/landesbank/annualreports.html?kid=108\&cHash=e565350eae95ec5e8ceafbfc1d955ed5 .

SBA Spa Consortile, 2018, Servizi offerti, availableat: https://www.sba.bcc.it.

Testo Unico delle Leggi sull'ordinamento delle Casse Rurali ed Artigiane, 1937, at: www.cooperazione.net . 